\title{
Uzupelnienia i uwagi do „Spisu urzędników mazowieckich z lat 1341-1462” (Na marginesie książki Anny Supruniuk, Mazowsze Siemowitów)
}

W 2010 r. ukazała się rozprawa Anny Supruniuk pt. Mazowsze Siemowitów (1341-1442). Dzieje polityczne i struktury władzy ${ }^{1}$. Książka składa się ze wstępu (s. 7-18) dwóch rozdziałów (s. 19-110), 10 map objaśniających podziały Mazowsza w latach 1341-1462 oraz obszernego aneksu (s. 123-226) zawierającego spis urzędników mazowieckich. On właśnie będzie przedmiotem moich rozważań. Dopełnieniem pracy jest wykaz skrótów, bibliografia oraz indeks osób. We wstępie (s. 7-18) Autorka uzasadniła podjęcie tematu, sposób jego realizacji, zakres chronologiczny i terytorialny oraz omówiła podstawę źródłową, stan badań i literaturę przedmiotu². Pierwszy rozdział stanowi syntezę dziejów politycznych Mazowsza w latach 1341-1462 opartą w dużej mierze na cennym opracowaniu tej Autorki, przygotowanym wspólnie z Henrykiem Samsonowiczem i zamieszczonym w Dziejach Mazowsza do $1526 r{ }^{3} \mathrm{~W}$ rozdziale drugim natomiast omówiono politykę wewnętrzną książąt mazowieckich, podziały terytorialne i administracyjne dzielnicy, funkcjonowanie sądownictwa ziemskiego na Mazowszu, kryteria powoływania urzędników, ich pozycję w strukturze władzy, oraz rolę poszczególnych rodów mazowieckich (tworzących elitę urzędniczą i otoczenie władców) oraz ich związki rodzinne i rodowe 4 .

Aneks stanowi uzupełnienie dwóch części pracy i obejmuje spis urzędników ziemskich i administracyjnych z lat 1341-1462, głównie z terytorium księstwa zachodnio-mazowieckiego. Przy opracowaniu spisu Autorka wykorzystała Studia Adama Wolffa (z wykazem urzędników mazowieckich) ${ }^{5}$

\footnotetext{
${ }^{1}$ Anna Supruniuk, Mazowsze Siemowitów (1341-1442). Dzieje polityczne i struktury władzy, Wydawnictwo DiG, Warszawa 2010, ss. 274, 10 map; indeks osób.

2 Do wstępu miałbym drobne uwagi. Do Metryki mazowieckiej zaliczamy obecnie 21 ksiąg kancelaryjnych. Jerzy Senkowski opublikował Księgę skarbową Janusza II z lat 1477-1490, która występuje w ramach Metryki Koronnej, jako pozycja $\mathrm{nr} 7$, nie $\mathrm{nr} 8$. MK 8 to Metryka zawierająca wpisy różnych książąt mazowieckich z lat 1471-1526 i została spisana dopiero po inkorporacji Mazowsza do Korony. Pierwsze dwa zeszyty Słownika historyczno-geograficznego województwa płockiego $w$ średniowieczu zostały opublikowane przez wydawnictwo Ossolineum we Wrocławiu. Praca Feliksa Kozłowskiego pt. Dzieje Mazowsza za panowania książąt ukazała się w 1858, natomiast publikacja Aleksandra Swieżawskiego o ziemi bełskiej w 1990 r. Jerzy Zathey tylko szczegółowo opisał rękopis zawierający m.in. fragmenty księgi kancelaryjnej Siemowita $\mathrm{V}$, nie sporządził jednak odpisu tego cennego zabytku z XV w.

${ }^{3}$ H. Samsonowicz, A. Supruniuk, Dzieje polityczne (połowa XIV_początekXVIw.), w: Dzieje Mazowsza, t. 1, red. H. Samsonowicz, Pułtusk 2006, s. 257-338.

${ }^{4}$ W II rozdziale przy omawianiu kariery duchownej przedstawicieli rodu Gozdawów (s. 108) Autorka nietrafnie przyjmuje, że Paweł Giżycki „po śmierci książąt Bolesława IV (10 IX 1454) i Władysława I (11/12 XII 1455) uczestniczył w rządach regencyjnych, które sprawował w obu dzielnicach Mazowsza w imieniu małoletnich książąt”. Biskup płocki uczestniczył w rządach regencyjnych tylko na Mazowszu zachodnim (księstwo płockie i ziemia bełska), natomiast na Mazowszu wschodnim po zgonie Bolesława IV (1454) regencję objęła jego matka Anna Fiodorówna, a po jej śmierci (1458) Barbara Aleksandrówna, wdowa po Bolesławie IV.

5 A. Wolff, Studia nad urzędnikami mazowieckimi 1370-1526, Warszawa 1962, Dodatek I. Spis urzędników, s. $284-302$.
} 
oraz własny spis zamieszczony w dysertacji o otoczeniu Siemowita $\mathrm{IV}^{6}$. Datę początkowo spisu wyznacza rok 1341, tj. objęcia rządów w księstwie czersko-warszawskim przez Siemowita III Trojdenowica. Natomiast cezurą końcową stanowi wygaśnięcie w 1462 r. (po śmierci Siemowita VI i Włodzisława II) linii zachodnio-mazowieckiej Piastów.

Przygotowany wykaz nawiązuje tylko w pewnym stopniu do spisów urzędników wydawanych pod redakcją Antoniego Gąsiorowskiego przez Polską Akademię Nauk i Bibliotekę Kórnicką w serii „Urzędnicy dawnej Rzeczypospolitej XII-XVIII wieku”, gdyż zawiera pełniejsze informacje o urzędnikach. Spis urzędników mazowieckich opracowany przez A. Supruniuk obejmuje następujące dane: 1. Imię, ewentualnie patronimik, przydomek, miejsce pochodzenia, przynależność rodowa (herb), informacje o rodzinie; 2. Daty graniczne sprawowania urzędu (pierwszy i ostatni zapis poświadczający jego pełnienie); 3. Powiązania między poszczególnymi osobami; 4. Wszystkie urzędy sprawowane przed nominacją, pełnione równocześnie oraz dalsze awanse; 5. Podstawowe dane bibliograficzne (opracowania na temat osoby lub jej rodziny). W spisach przyjęto podział na poszczególne ziemie w granicach księstwa zachodnio-mazowieckiego, a w ramach każdej z nich zastosowano układ alfabetyczny według miejscowości. W porządku alfabetycznym umieszczono także urzędy w obrębie każdej hierarchii (od chorążego do wojskiego), z uwzględnieniem urzędników administracyjnych (starostów, rządców). Nazwiska osób sprawujących dany urząd uporządkowano według kolejności jego pełnienia.

Zanim przystąpię do uzupełnienia Spisu urzędników mazowieckich chciałbym odnieść się do ważnej problematyki, mianowicie roli kanclerzy (nadwornych i ziemskich) na Mazowszu książęcym. Andrzej Marzec w recenzji z pracy A. Supruniuk zwrócił uwagę, że „kwestia kanclerstwa nie została w ogóle sprecyzowana i nie wiadomo, jak należy kwalifikować tę godność w realiach piętnastowiecznego Mazowsza, ile takich urzędów było w skali księstwa i które z nich mogły być traktowane, jako ziemskie, a które jako dworskie”7. Powołał się też na przykład Korony, gdzie „w XIV i XV w. kanclerstwa pozostawały ściśle związane $\mathrm{z}$ dworem królewskim, a nie z hierarchiami ziemskimi, choć często poprzez nazwę związane były z którąś z ziem Królestwa”. Podzielam opinię tego badacza. Występowanie na liście świadków i w formułach kancelaryjnych kanclerzy ziemskich (w XIV-XV w.) wymaga szczegółowego objaśnienia, gdyż jest ważne nie tylko dla poznaniu dziejów i organizacji kancelarii książęcych na Mazowszu. Specyfiką tej dzielnicy było kierowanie zarządem skarbowym przez kanclerzy i podkanclerzych; kompetencje kanclerza w tym zakresie odpowiadały kompetencjom podskarbiego w Koronie. Dlatego urzędnicy kancelarii byli zarazem pisarzami skarbu książęcego i prowadzili księgi skarbowe dworu. Z kancelarią książęcą związani byli także kanclerze ziemscy. Urząd ten rozwinął się z urzędu kanclerza nadwornego, który zajmował się skarbowością. W czasach Siemowita III pojawili się pierwsi kanclerze dzielnicowi, co jest związane z podziałem Mazowsza na dzielnice (districtus). Każda z nich miała własnego kanclerza. W drugiej połowie XIV w. spotykamy nie tylko kanclerzy czerskiego i rawskiego (w związku z głównymi ośrodkami władzy książęcej), ale również gostynińskiego, ciechanowskiego i zakroczymskiego. Kanclerz dzielnicowy prawdopodobnie zorganizował wówczas i prowadził kancelarię ziemską, tzn. rejestrował posiedzenia i wyroki sądu ziemskiego w zakładanych wtedy księgach sądowych, wystawiał dokumenty sądowe, a także prowadził nowo założone rejestry podatkowe ${ }^{8}$. Jego współpracownikiem był pisarz (notarius), który przejął wkrótce większość albo nawet całość jego zadań i przyjął tytuł pisarza ziemskiego. W XV w. księgi sądowe były prowadzone już przez pisarzy i podpisków ziemskich. Kanclerzowi pozostało jednak znaczne uposażenie, które w praktyce łączono najczęściej z urzędem kanclerza nadwornego. Pierwszym znanym kanclerzem ziemskim gostynińskim był Wit, poświadczony już w 1358 r. i to na

\footnotetext{
${ }^{6}$ A. Supruniuk, Otoczenie księcia mazowieckiego Siemowita IV (1374-1426). Studium o elicie politycznej Mazowsza na przełomie XIV i XV wieku, Warszawa 1998, Aneks 1. Wykazy urzędników, s. 287-308.

7 A. Marzec, rec. A. Supruniuk, Mazowsze Siemowitów (1341-1442). Dzieje polityczne i struktury władzy, Warszawa 2010, Przegl. Hist., 103, 2012, nr 1, s. 211.

${ }^{8}$ K. Pacuski, Możnowładztwo i rycerstwo ziemi gostynińskiej w XIV-XV wieku, Warszawa 2009, s. $416 \mathrm{n}$.
} 
pierwszym miejscu na liście świadków (przed sędziami czerskim i sochaczewskim), co ukazuje jego znaczenie w hierarchii władzy. Najpóźniej w 1360 r. kanclerzem księcia Siemowita III został Paweł, który równocześnie był kanclerzem ziemskim czerskim i rawskim ${ }^{9}$. Po jego rezygnacji kanclerzem książęcym został w 1363 r. Arnold, który podobnie jak jego poprzednik łączył urząd kanclerza na dworze $\mathrm{z}$ kanclerstwem ziemskim czerskim i rawskim ${ }^{10}$. Arnold w kancelarii książęcej pracował do 1367 r. Ostatnim pracownikiem łączącym funkcje w kancelarii dworskiej Siemowita i kanclerstwa ziemskie - choć zjawisko to wraca w latach późniejszych — był Jakub. Pojawił się on w kancelarii Siemowita III jako pisarz (1368), będąc również plebanem w Białej w ziemi rawskiej (gdzie kościół należał do patronatu książęcego) ${ }^{11}$, a potem (1371) został podkanclerzym ${ }^{12}$. To on był odpowiedzialny za redakcję oraz spisywanie dokumentów, stając się twórcą jednolitego stylu kancelarii Siemowita III, choć korzystał pewnie ze wskazówek uczonego kanclerza Dobrogosta Nowodworskiego. Sam kanclerz pełnił jednak wyłącznie funkcje polityczne i nie zajmował się pracą nad dokumentami ${ }^{13}$. Jakub został następnie (pod koniec 1372 r.) kanclerzem ziemskim zakroczymskim i ciechanowskim oraz kanonikiem płockim ${ }^{14}$ (przy czym kanclerstwo zakroczymskie stracił w 1374 r. po przekazaniu tej ziemi młodemu księciu Januszowi I, który powołał nowego kanclerza Floriana). W późniejszym okresie (1374-1381) w kancelarii Siemowita III nie występują już pracownicy, którzy byli równocześnie kanclerzami ziemskimi. W kancelarii jednak jego synów, Janusza I i Siemowita IV, znamy urzędników kancelaryjnych, którzy łączyli pracę w kancelarii dworskiej z kanclerstwem ziemskim. W księstwie czersko-warszawskim do czasu zniesienie urzędów kanclerzy ziemskich (1406) znamy Więcława, kanclerza Janusza I i równocześnie kanclerza ziemskiego zakroczymskiego oraz Dominika z Kłodna, kanclerza dworskiego i kanclerza ziemskiego czerskiego. Siemowit IV nie zlikwidował w swoim księstwie urzędów kanclerzy ziemskich. Z okresu jego rządów (1373-1426) znamy pracowników kancelarii książęcej, którzy byli równocześnie kanclerzami ziemskimi. Są to: Henryk (kanclerz ziemski wiski), Grzymisław z Krzykos (kanclerz ziemski ruski), Stanisław Pawłowski (kanclerz ziemski rawski, sochaczewski, ruski), Czambor z Iłowa (kanclerz ziemski rawski, ruski), Michał z Boryszewa (kanclerz ziemski gostyniński). Po śmierci Siemowita IV jego synowie sprawujący rządy w braterskim niedziale (1426-1434) zachowali urzędy kanclerzy ziemskich. Także po podziale schedy po Siemowicie IV książęta nie zlikwidowali we własnych dzielnicach urzędów kanclerzy ziemskich; byli oni równocześnie pracownikami kancelarii książęcych. W księstwie Siemowita V (1434-1442) jego kanclerz nadworny Gotard z Rybna i Babska był równocześnie kanclerzem ziemskim gostynińskim, a pisarz książęcy Mikołaj ze Słonkowa kanclerzem sochaczewskim. W dzielnicy Włodzisława I (1434-1455) kanclerz książęcy Stanisław z Gołocina był równocześnie kanclerzem ziemskim wiskim. Osobnego omówienia wymaga postać Racibora z Golejewa (zm. 1481), kolejno kanclerza dworskiego księcia Włodzisława I (od czerwca 1450 r.) i jego synów (Siemowita VI i Włodzisława II) do 1462 r., a następnie kanclerza synów Bolesława IV. Po podziale dzielnicy (3 IV 1471) pozostał kanclerzem księstwa płockiego, które przypadło Kazimierzowi III. Używał wówczas najczęściej tytułu kanclerza książęcego (cancellarius noster). W 1475 po sprzedaży ziemi płockiej, wiskiej i zawkrzeńskiej przez Kazimierza III swemu bratu Januszowi II pozostał na stanowisku kanclerza księstwa płockiego. Na dokumentach Janusza II dotyczących księstwa płockiego występował jako kanclerz płocki (cancellarius noster Plocensis). Zauważmy, że w latach 1471-1481 kanclerzem dworu Janusza II był Piotr z Chodkowa,

\footnotetext{
9 J. Grabowski, Kancelarie i dokumenty książą mazowieckich w latach 1341-1381. Ośrodki zarządzania i kultury, Warszawa 1999, s. 249.

10 Tamże, s. $250 \mathrm{n}$.

${ }^{11}$ NKDMaz., t. 3, nr 98; A. Radzimiński, Prałaci i kanonicy kapituły katedralnej płockiej w XIV i pot. XV w. Studium prozopograficzne, t. 2, Toruń 1993, s. 60.

12 NKDMaz., t. 3, nr 114; sądzę, że awans otrzymał już w końcu 1370 r., wkrótce po objęciu ziemi płockiej przez Siemowita.

13 J. Grabowski, Intelektualiści w kancelarii książęcej na Mazowszu w XIV i pierwszej połowie XV w. Ze studiów nad elita umysłowa na ziemiach polskich, w: Genealogia. Stan i perspektywy badań nad społeczeństwem Polski średniowiecznej na tle porównawczym, red. J. Pakulski, J. Wroniszewski, Toruń 2003, s. 218 n.

14 ZDm.Pł., t. 1, nr 42.
} 
jednak zakres jego obowiązków nie obejmował ziemi płockiej. Prowadzenie oddzielnego rejestru (metryki płockiej) było spowodowane tym, że po włączeniu księstwa płockiego do dzielnicy Bolesławowiców (1462), terytorium to zachowało (pod rządami Konrada III) pewną autonomię, co było ceną za poparcie udzielone przez lokalną elitę urzędniczą synom Bolesława IV w ich konflikcie z królem polskim. Racibor urząd kanclerza płockiego sprawował do końca życia (1481). Był zarazem ostatnim na Mazowszu pracownikiem kancelarii książęcej, który używał tytułu kanclerza dzielnicowego.

\section{Uzupełnienia do „Spisu urzędników z lat 1341-1462”}

\section{Urzędnicy belscy}

\section{KANCLERZ}

Grzymisław (Grzymek) z Krzykos h. Pobóg nominację na kanclerstwo bełskie (ruskie) otrzymał przed 3 V 1388 (AGAD, Płockie gr. wiecz. 159, s. 740). W otoczeniu Siemowita IV pojawił się 19 VII 1383 jako kapelan książęcy, jednak był równocześnie pisarzem nadwornym. A. Supruniuk (Otoczenie, s. 169) nietrafnie sądzi, że kapelan książęcy o imieniu Grzymek i kanclerz książęcy Grzymisław z Krzykos to dwie różne osoby. Najpóźniej na początku sierpnia 1383 awansował na urząd podkanclerzego książęcego. Świadczy o tym dokument Siemowita IV z 10 VIII $1383^{15}$ gdzie wystąpił na liście świadków (Grzimislao vicecancellario curie nostre). 7 IX 1383 zredagował ważny dokument Siemowita IV dla Stanisława Grada i wystąpił w formule datum per manus jako podkanclerzy książęcy ${ }^{16}$. Po objęciu przez Siemowita IV ziemi bełskiej (1387/88) otrzymał nominację (przed 3 V 1388) na urząd kanclerza ruskiego (ziemi bełskiej).

Czambor z Iłowa h. Rogala z urzędem kanclerza ruskiego (bełskiego) i mazowieckiego wystąpił na dokumencie Siemowita IV z 20 XII 1424 (AGAD, MK 96, k. 156-157v. Autorka omyłkowo odesłała do MK 94, k. 156-157v). Określenie „kanclerz mazowiecki” nie oznacza, że był już kanclerzem nadwornym. Czambor był wcześniej pisarzem w kancelarii Siemowita IV (1414), sekretarzem (1421) oraz kanonikiem płockim i plebanem w Białej, następnie (1422) został podkanclerzym ${ }^{17}$, łącząc ten urząd z kanclerstwem ziemskim rawskim i ruskim ${ }^{18}$. Po elekcji Stanisława Pawłowskiego na biskupstwo płockie (1425) awansował na urząd kanclerza nadwornego (przed 20 VIII 1425), który sprawował do końca życia Siemowita IV ${ }^{19}$ oraz w początkowym okresie rządów niedzielnych jego synów (do 1427).

\section{Busk}

\section{STAROSTA}

Gotard (Jan) Mycowski z Mycowa: 1441, 1444, Urzędnicy województwa betskiego i ziemi chetmskiej XIV-XVIII wieku. Spisy [dalej: Urzędnicy woj. betskiego], oprac. H. Gmiterek, R. Szczygieł, Kórnik 1992, nr 606.

Stanisław Rogożowski h. Dołęga: 9 VII 1450 (AGAD, MK 335, k. 56); 1451 (tamże, k. 62); Urzędnicy woj. betskiego, nr 607; K. Pacuski, Możnowładztwo, s. 55

\footnotetext{
15 Wiadomość historyczna o rodzie Świnków oraz rodowód pochodzacej od nich rodziny Zielińskich herbu Świnka, zebrane przez G. i J. Zielińskich, cz. 1, Toruń 1880, dodatek źródłowy, s. 126.

${ }_{16}$ J. Grabowski, Najstarsze przywileje książąt mazowieckich dla Szreńska, „Średniowiecze Polskie i Powszechne”, 4, 2007, s. $129-132$.

17 A. Supruniuk, Otoczenie, s. 204.

${ }^{18}$ Kanclerzem rawskim został przed 4 VIII 1422 (Iura Masoviae terrestria, wyd. J. Sawicki, t. 1, Warszawa 1972, nr 67), natomiast ruskim przed 20 XII 1424 (AGAD, MK 96, k. 157v).

19 Wystąpił, jako kanclerz nadworny na ostatnim znanym dokumencie Siemowita IV z 29 XII 1425 r. (AGAD, Płockie ziem. wiecz. rel. wyroki 3, skł. I, k. 4v.-5v.) w zapisie o brzmieniu: Czambor canonico Plocensi et cancellario aule nostre, qui presencia habuit in commissis.
} 
Wacław ze Słubicy: 1-3 X 1453 (K. Sochaniewicz, A. Wolff, Urzędnicy woj. betskiego do połowy XVI w., Mies. Herald., 10, 1931, s. 19; Urzędnicy woj. betskiego, nr 608).

Mikołaj Mnich z Wiśniowa: 31 X 1457 (A. Wolff, Studia, s. 305; Urzędnicy woj. betskiego, nr 609).

\section{Urzędnicy czerscy}

\section{CHORĄŻY}

Nadbor z Chamska i Niechanina h. Bolesta urząd chorążego sprawował co najmniej do 1393: 15 VIII 1393 (AGAD, Zbiór Kapicy Milewskiego [dalej: Kapicjana] 57, s. 538); 22 IX 1393 (AP Kraków, Zbiór Glogera 46, s. 831).

\section{KANCLERZ}

Gunter z Brześcia był kanclerzem nadwornym Trojdena I (1327) a następnie kanclerzem nadwornym Siemowita III i Kazimierza I (1341) pozostających w braterskim niedziale do 1349 (J. Grabowski, Kancelarie, s. 242 n.). Określenie kanclerz czerski oraz kanclerz warszawski należy rozumieć jako tytuł przyjęty od głównych ośrodków władzy książęcej. Pierwszym znanym kanclerzem ziemskim na Mazowszu był dopiero Wit, kanclerz ziemski gostyniński (1358).

Jan, dziekan płocki i kanclerz książęcy (Siemowita III i Kazimierza I) nie był kanclerzem ziemskim czerskim. Jan w zachowanych dokumentach występuje, jako kanclerz mazowiecki, tj. książęcy (NKDMaz., t. 2, $\mathrm{nr}$ 280, 281, J. Grabowski, Kancelarie, s. 244 n.). Potwierdza to również dokument z 30 VI - 6 VII 1347 arcybiskupa gnieźnieńskiego Jarosława, gdzie Jan wystąpił w testacji (obok pisarza Tylona), jako kanclerz książęcy: Johanne cancellario et Tylkone notario dicti ducis (NKDMaz., t. 2, nr 282).

\section{Urzędnicy gostynińscy}

\section{CHORĄŻY}

Mikołaj zw. Gęba z Trębek h. Prawda. Można uściślić podaną za A. Wolffem (Studia, s. 290) datę roczną 1444, gdyż Mikołaj z urzędem chorążego wystąpił 6 VI 1444 (MK 340, k. 170); 21 X 1444 (MK 341, k. 24v).

Stanisław z Sokołowa h. Dołęga nie występuje 18 V 1473 z urzędem chorążego gostynińskiego tylko jako łowczy gostyniński (S. Szybkowski, Możnowładztwo i szlachta ziemi gostynińskiej w późnym średniowieczu. Uzupetnienia genealogiczne i prozopograficzne, „Rocznik Mazowiecki”, 23, 2011, s. 21).

\section{KANCLERZ}

Wit, kanclerz gostyniński z nominacji Siemowita III (1358) był wcześniej pisarzem książęcym Siemowita II, znanym z lat 1313-1333 i występującym z przydomkiem Polak (Polonus) ${ }^{20}$.

Gotard z Babska i Rybna h. Radwan przed objęciem urzędu kanclerza Siemowita V był pisarzem dworu książęcego 28 XII 1434 (BKórn., rkps 194, k. 39). Z tytułem kanclerza gostynińskiego występuje jeszcze później: 3 III 1444 (AGAD, MK 337, k. 131v); 22 VII 1444 (tamże 341, k. C 15v).

\section{PODCZASZY}

Świętosław z Piotrowa i Sojek h. Grzymała wzmiankowany w uszkodzonym dokumencie synów Siemowita IV z 2 VII [1432], AGAD, dok. perg., nr 8911 (ustalenie datacji J. Grabowski, Dynastia Piastów mazowieckich. Studia nad dziejami politycznymi Mazowsza, intytulacją i genealogia książat, Kraków 2012, s. 471 n.). W Spisie niewłaściwie odesłano do dok. perg. nr 891 w AGAD, gdyż jest to dokument króla Kazimierza Jagiellończyka z 21 V 1489 dla Dobiesława z Kurozwęk.

${ }^{20}$ NKDMaz., t. 2, nr 140, 145, 207. 


\section{SEDZIA}

Jakub h. Luba (?) to według K. Pacuskiego (Możowładztwo, s. 416) Jakub Poczta z Czernin i Miszewa h. Luba, który objął urząd po 7 VI 1409 (wcześniej był podsędkiem).

Sasin zw. Lelek ze Szczawina h. Prawda urząd sędziego gostynińskiego objął pod koniec 1434, gdyż już 1 I 1435 występował, jako sędzia (S. Szybkowski, Możnowtadztwo i szlachta, s. 20).

\section{STAROSTA}

Tomasz zw. Siestrzeniec z Nadarzyna, Ruśca h. Radwan starostą gostynińskim został rzeczywiście przed 21 IX 1436, jednak odnotowany jest w MK 335 (nie 336), k. 79 . W 1441 r. wystąpił również na zachowanym w oryginale dokumencie Siemowita V z 16 czerwca (AD Włocławek, dok. perg. 281).

\section{STOLNIK}

Mikołaj z Kutna h. Ogon stolnikiem gostynińskim był jeszcze 26 VII 1464 (S. Szybkowski, Możnowladztwo i szlachta, s. 14).

\section{Urzędnicy płoccy}

\section{CZEŚNIK}

Jan z Dłutowa h. Wężyk cześnikiem płockim został przed 21 IV 1435 (AGAD, MK 335, k. 104v).

\section{KANCLERZ}

Ulryk z Kępy nominację na urząd kanclerza otrzymał wcześniej niż podano w Spisach, mianowicie przed 3 V 1388 (AGAD, Płockie gr. wiecz. 159, s. 740). Po odejściu Henryka z kancelarii został kanclerzem książęcym (tj. księstwa płockiego Siemowita IV). Po swoim poprzedniku objął również prepozyturę w kolegiacie płockiej. Jako „nasz kanclerz płocki” wystąpił w formule per manus na ważnym dokumencie Siemowita IV z 1385 r. dotyczącym ugody z królową Jadwigą Andegaweńską ${ }^{21}$. Po awansie Grzymisława z Krzykos (dotychczasowego pisarza i kapelana) na kanclerstwo ruskie, Ulryk zaczął się tytułować (oprócz nadal używanego określenia kanclerz płocki) „,kanclerzem generalnym” (niekiedy z dodatkiem: „mazowiecki”, ,płocki”)22 lub „kanclerzem całego Mazowsza” (tocius Mazouie cancellarius) ${ }^{23}$. W $1401 \mathrm{r}$. zrezygnował z pracy na rzecz kancelarii książęcej, pozostając nadal prepozytem w kolegiacie św. Michała. Zmarł ok. $1416 \mathrm{r}$.

Racibor z Golejewa, kanclerz. W Spisach (s. 167) podano, że był pisarzem (notariuszem) ziemi płockiej w latach 1443-1450. Natomiast przy wykazie pisarzy płockich jest umieszczona data 27 XII 1443 (s. 170), a w przypisie na tej samej stronie informacja, że pisarzem ziemi płockiej był od $1437 \mathrm{r}$. Racibor występował od 1437 r. jako pisarz ziemski płocki, co potwierdzają także wpisy do Metryki. W kancelarii książęcej pojawił się dopiero po śmierci Stanisława z Gołocina (zmarłego na przełomie marca i kwietnia 1449 r.) W testacji występuje obok pisarzy dworskich Marcina z Jeżewa h. Bolesta, Jakub z Kłobukowa h. Kuczaba i Pawła z Belska. Jeszcze 12 IV 1450 spotykamy go, jako pisarza płockiego. Dopiero przed 11 VI 1450 (AGAD, MK 36, s. 909-910) wystąpił z formułą datum per manus, jako kanclerz książęcy. Racibor zmarł nie przed 15 VII 1483, lecz 28 IX 1481 co odnotowano w Metryce książęcej (AGAD, MK 6, k. 139ev).

\section{KASZTELAN}

Szczepan Goły z Miszewa i Szczytna h. Prus urząd kasztelana płockiego objął przed 1 XI 1468 (AGAD, MK 5, k. 109).

\footnotetext{
${ }^{21}$ Iura Masoviae terrestria, t. 1, $\mathrm{nr} 30$.

${ }^{22}$ AGAD, MK 70, k. 498-500; ZDm.Pł., t. 1, nr 55; NKDMaz., t. 3, nr 233 (data powinna być poprawiona na 2 I 1390 ).

23 AGAD, MK 6, k. 249.
} 


\section{PISARZ}

Ambroży, pisarz ziemski płocki (nie wymieniony w Spisach) znany 11 III 1392 (AGAD, Płockie gr. wiecz. 159, s. 750).

\section{PODSĘDEK}

Piotr Grzymała z Brochocina h. Grzymała znany jest później: 9 I 1391 (AGAD, Płockie gr. wiecz. 159, s. 746); 11 III 1392 (tamże, s. 750).

Ninogniew z Łaszewa, Grodzanowa h. Prawda urząd podsędka objął przed 16 X 1434 (AGAD, MK 335, k. 7).

Andrzej z Kars h. Bolesta był podsędkiem jeszcze 7 IV 1467 (AGAD, MK 337, k. 22; B. Sobol, Sejm i sejmiki ziemskie na Mazowszu książęcym, Warszawa 1968, s. 85).

\section{PODSTOLI}

Zawisza z Dłużniewa, Kondrajca h. Dołęga urząd podstolego objął przed 8 I 1432 (AGAD, Płockie gr. wiecz. 85, k. 87) i pełnił co najmniej do 18 V 1440 (AGAD, MK 340, k. 128).

Guntek (Gundek) ze Ślepkowa i Ciołkowa h. Bolesta urząd podstolego objął przed 6 VI 1440 (AGAD, MK 340, k. 128v); występuje następnie 7 VIII 1440 (tamże, k. 133).

Krystyn ze Szreńska h. Dołęga, podstolim płockim został przed 7 IV 1445 (AGAD, MK 70, k. 182); występuje również: 22 V 1445 (tamże, MK 337, k. 113v); 28 VIII 1446 (tamże, MK 335, k. 110v).

Szczepan Goły z Miszewa i Szczytna h. Prus podstolim płockim został przed 15 V 1451 (AGAD, MK 335, k. 37v). Z urzędem podstolego występuje co najmniej do 1 VIII 1463 (tamże, MK 337, k. 8v).

\section{STAROSTA}

Szczepan z Jasieńca h. Wężyk urząd starosty sprawował również w 1388 (AGAD, MK 70, k. 498v500).

Zawisza z Dłużniewa, Kondrajca h. Dołęga z urzędem starosty płockiego występuje już 8 I 1432 (AGAD, Płockie gr. wiecz. 85, k. 87). Natomiast znany jest do 29 VII 1437 (K. Pacuski, PSB, t. 43, 2005, s. 167).

Szczepan (Stefan) starosta to Szczepan Goły z Miszewa i Szczytna h. Prus. Starostą płockim został przed 5 VIII 1437 (AGAD, MK 336, k. 69v). Natomiast w 1438 r. jako starosta świadczy: 6 kwietnia (tamże, MK 335, k. 14v); 16 kwietnia (tamże, k. 15); 15 maja (tamże, k. 15v); 19 maja (tamże, k. 15v), 29 czerwca (tamże, k. 19), 30 czerwca (tamże, k. 19v). Urząd starosty pełnił prawdopodobnie do 28 VIII 1438.

Marcin zw. Śledź z Miszewa Śledziowego h. Prus z urzędem starosty występuje wcześniej niż podano w Spisach: 9 IX 1438 (AGAD, MK 335, k. 23).

Jan zw. Szyroka starostą płockim został przed 14 VII 1439 (AGAD, MK 336, k. 79); znany również 13 X 1443 (tamże, MK 26, k. 16).

Jan Kopacz z Osin i Lubowidza h. Rawa jako starosta płocki i łowczy rawski występuje jeszcze 15 IV 1444 (AGAD, MK 337, k. 135).

Jan zw. Szarukan z Wierzbicy Pańskiej starostą płockim został przed 1 IV 1445 (AGAD, MK 336, k. 55v); znany również 7 III 1446 (AGAD, Płockie gr. wiecz. diss. 1, s. 731).

Mikołaj z Podkrajewa h. Rogala starostą płockim został przed 28 II 1447 (AGAD, MK 336, k. 23v); 6 III 1447 (tamże, Płockie ziem. rel. i wyr. 1, skł. XIII, k. 16). Znany jest również: 7 XII 1450 (tamże, Płockie ziem. rel i wyr. 2, skł. III, k. 22v); 15 V 1451 (tamże, MK 335, k. 37v), 29 III 1452 (tamże, k. 128); 14 VII 1455 (tamże, Płockie gr. wiecz. diss. 1, s. 184); 21 VI 1456 (tamże, Płockie ziem. rel. i wyr. 1, skł. XV, k. 82). Ponownie starostą płockim został 28 VIII 1461 r. o czym świadczy dokument Siemowita VI z 26 IX 1461 na którym wystąpił na liście świadków, jako sędzia zawkrzeński i starosta płocki (AGAD, dok. perg., nr 624). 
Sasin z Radzanowa h. Prawda z urzędem starosty wystąpił jeszcze 20 V 1454 (AGAD, Płockie ziem. rel. i wyr. 1, skł. VI, k. 41v); 15 VII 1454 (tamże, skł. LVI, k. 264v).

\section{WOJSKI}

Mikołaj z Ośnicy i Piastowa urząd wojskiego objął przed 18 VI 1434 (AGAD, MK 335, k. 2v). Podana w Spisach data występowania tego urzędnika: lipiec 1434 (tamże, MK 335, k. 7v) powinna być rozwiązana na 22 X 1434.

Guntek ze Ślepkowa h. Bolesta wojskim płockim został przed 13 X 1443 (AGAD, MK 26, k. 16).

\section{Urzędnicy płońscy}

Przy wykazie urzędników płońskich (s. 186, przyp. 34) należało podać, że Płońsk i powiat sądowy płoński stanowiły oprawę księżnej Katarzyny Siemowitówny (żony Michała Bolesława), która sprawowała tam rządy od lat czterdziestych XV w. do śmierci w 1480 r. Po tragicznym zgonie teścia, Zygmunta Kiejstutowicza, w marcu 1440 r., jej mąż utracił ojcowiznę, a Katarzyna powróciła na Mazowsze. Księżna otrzymała od swych braci zaopatrzenie w postaci Płońska, który należał do dzielnicy Włodzisława $\mathrm{I}^{24}$. Posiadanie przez nią „oprawy płońskiej” zaakceptowali synowie Bolesława IV, po objęciu ziemi płockiej w $1462 \mathrm{r}$.

\section{STAROSTA}

Andrzej z Borzewa (nie wymieniony w Spisach) jako starosta płoński występuje: 1456 (AGAD, MK 337, k. 67v); 1458 (tamże, Płockie gr. wiecz. diss. 1, s. 737); 1459 (tamże, MK 335, k. 168v), 1461 (tamże, Zakroczymskie ziem. wiecz. rel. 6, k. 16v).

\section{WOJSKI}

Jan (Jasiek) z Głożka objął urząd wojskiego przed 14 VI 1434 i sprawował co najmniej do 8 IV 1437 (AGAD, MK 335, k. 163v).

\section{Raciąż}

\section{KASZTELAN}

Zawisza z Kondrajca, Dłużniewa h. Dołęga urząd objął przed 4 IX 1440 (AGAD, MK 340, k. 133); znany również 9 VI 1446 (tamże, MK 335, k. 6v).

Jan z Miszewa h. Grzymała urząd kasztelana raciąskiego objął przed 15 V 1451 (AGAD, MK 335, k. 38).

Jan z Koziebród h. Bolesta urząd kasztelana objął przed 13 VI 1468 (AGAD, Płockie gr. wiecz. diss. 1, s. 777).

\section{Urzędnicy rawscy}

\section{CHORĄŻY}

Męcina z Żelaznej i Żelichlina h. Rawa występuje jako chorąży 28 VI 1453 (J. Tęgowski, Matżeństwo Piastówny mazowieckiej Małgorzaty z księciem oleśnickim Konradem IX Czarnym, w: Korzenie wielokulturowości Śląska ze szczególnym uwzględnieniem Śląsa Górnego, red. A. Barciak, Katowice-Zabrze 2009, Dodatki źródłowe I, s. 309).

\footnotetext{
${ }^{24}$ Iura Masoviae terrestria, t. 1, nr 78. Włodzisławowi I przypadła m.in. ziemia płońska oraz miasto Płońsk.
} 


\section{KASZTELAN}

Stogniew z Głuchowa urząd kasztelana rawskiego objął przed 22 VI 1434. Wystąpił na dokumencie z 22 VI 1434 (AGAD, dok. perg. nr 8633) wystawionym w Płocku przez Siemowita V, Kazimierza II i Trojdena II dla Pakosza z Solca, prawdopodobnie w dniu pogrzebu matki Aleksandry Olgierdówny (J. Grabowski, Dynastia Piastów, s. 451 ).

\section{ŁOWCZY}

Jan Kopacz z Osin h. Rawa urząd łowczego objął przed 2 X 1435 (BCzart., dok. perg. nr 408) i sprawował co najmniej do 7 IV 1445 (AGAD, MK 70, k. 182).

\section{PISARZ}

Jan z Chociwa w ziemi rawskiej (nie uwzględniony w Spisach) wystąpił 28 IV 1449 (AGAD, MK 337, k. 70v) jako pisarz rawski. Natomiast 16 IX 1451 (tamże, MK 335, k. 49) wymieniony w testacji (nieprawidłowo) jako podpisek.

\section{PODCZASZY}

Wojciech z Sadkowic z urzędem podczaszego występuje jeszcze pod koniec kwietnia 1449 (AGAD, MK 337, k. 70v).

Jakub z Trębaczewa w ziemi rawskiej (nie wymieniony w Spisach) pełnił urząd podczaszego rawskiego: 26 IX 1457 (AGAD, MK 335, k. 146v); 5 II 1458 (tamże, k. 149); 30 X 1461 (tamże, k. 175).

\section{PODKOMORZY}

Lebor z Kowalewa (nie wymieniony w Spisach) wystąpił z urzędem podkomorzego rawskiego na dokumencie synów Siemowita IV z 22 VI 1434 (AGAD, dok. perg. nr 8633). Jednak już 26 X 1434 (tamże, MK 66, k. 222v) z urzędem podkomorzego rawskiego występuje Jan Tabasz z Załusek h. Junosza. Potwierdza to wpis z 31 X 1435 (tamże, MK 335, k. 8v), na którym Lebor występuje bez urzędu, podobnie jak 3 VI 1435 (tamże, k. 84v). Przed 18 VII 1435 Lebor z Kowalewa został ochmistrzem dworu księżnej Katarzyny Siemowitówny (tamże, dok. perg. nr 3480).

Jan Tabasz z Załusek h. Junosza urząd podkomorzego rawskiego objął przed 26 X 1434 (AGAD, MK 66, k. 222v) i pełnił go co najmniej do 5 VI 1441 (tamże, MK 17, k. 47v).

\section{PODSECEK}

Andrzej z Prus z urzędem podsędka znany również 27 III 1440 (J. Grabowski, Dynastia Piastów, Aneks I, nr 15, przyp. 235).

Piotr z Głowna jako podsędek rawski występuje po 29 VI 1448: 1451 (AGAD, MK 335, k. 45), 1453 (tamże, MK 337, k. 86); 1460 (tamże, k. 169), 1461 (tamże, k. 175).

\section{PODSTOLI}

Mikołaj Forstek z Prądnika (ob. Promnik) (nie odnotowany w Spisach) znany jako podstoli rawski: 20 VII 1450 (AGAD, MK 335, k. 57); 26 IX 1457 (tamże, k. 146v).

\section{SĘDZIA}

Jan Kopacz z Osin i Lubowidzy h. Rawa znany jako sędzia 24 VI 1446 (AGAD, MK 335, k. 108v). Jan Kaszyk z Głowna h. Pierzchała rzeczywiście wystąpił z urzędem sędziego 26 XI 1443, jednak podana sygnatura - AGAD, Archiwum Nieborowskie Radziwiłłow 80 - jest niewłaściwa. Archiwum Nieborowskie Radziwiłłów od wielu lat ma nowy inwentarz (opracowany przez V. Urbaniak). Dokument Włodzisława I z 26 XI 1443, na którym Jan Kaszyk z Głowna wystąpił jako sędzia rawski 
ma sygnaturę: AGAD, AR z Nieborowa 148, s. 27-2925. Podana natomiast w Spisach jednostka archiwalna (nr 80) zawiera rachunki bankowe $\mathrm{z}$ lat 1874-1941 księcia Janusza Radziwiłła.

Mikołaj Okuń z Rylska (nie uwzględniony w Spisach) wystąpił z urzędem sędziego rawskiego 5 VI 1453 (AGAD, MK 337, k. 86); znany jest również później 30 X 1461 (tamże, MK 335, k. 175).

\section{STAROSTA}

Mikołaj Okuń z Rylska w ziemi rawskiej (nie uwzględniony w Spisach) z urzędem starosty rawskiego występuje: 8 V 1446 (AGAD, MK 37, k. 419v); 24 VI 1446 (tamże, MK 335, k. 108v); 17 VI 1447 (tamże, k. 35); 2 XI 1447 (tamże, k. 133v), 22 XII 1447 (tamże, k. 135); 17 VI 1448 (tamże, MK 341, k. 21v); 1453 (tamże, MK 337, k. 10v); 14 III 1454 (tamże, k. 93v).

Wojciech zw. Chyliński z Chylina z urzędem starosty rawskiego występuje: 8 VIII 1451 (AGAD, MK 335, k. 45v); 28 VI 1455 (tamże, MK 78, k. 170v); 28 IX 1455 (tamże, MK 136, k. 154-156).

Wojciech z Sadkowic podkomorzy wystąpił równocześnie z urzędem starosty rawskiego 14 IV 1456 (AGAD, MK 337, k. 66).

Pakosław (Pakosz) z Rokitnicy h. Prawda (nie wymieniony w Spisach) znany jako starosta rawski 2 II 1458 (AGAD, MK 335, k. 148v).

\section{STOLNIK}

Dziersław (Dzierżek) Kopacz z Kurzeszyna z urzędem stolnika rawskiego występuje również później 27 III 1440 (J. Grabowski, Dynastia Piastów, Aneks źródłowy, nr 15).

\section{WOJEWODA}

Jan Kwaczała z Nieborowa h. Prawda (wojewoda rawski) był wcześniej marszałkiem dworu Siemowita V, jednak pełnił ten urząd od 1434; świadczy o tym dokument Siemowita V z 26 X 1434 (AGAD, MK 66, k. 222v), na którym wystąpił z formułą habuit in commisso, jako marszałek dworu książęcego.

\section{WOJSKI}

Mikołaj Małocha z Wilkowa h. Grzymała (nie uwzględniony w Spisach) występuje jako wojski rawski w latach 1446-1458: 8 V 1446 (AGAD, MK 37, k. 419v); 9 VII 1450 (tamże, MK 335, k. 56); 8 VIII 1451 (tamże, k. 45); 25 I 1458 (tamże, k. 147v).

\section{Kasztelanowie sierpeccy}

Mikołaj z Niedarzyna h. Prawda urząd kasztelana sierpeckiego objął przed 3 VI 1435 (AGAD, MK 355, k. 84v). Jest poświadczony także później: 14 IX 1447 (tamże, MK 335, k. 13v); 22 XII 1447 (tamże, k. 135).

Paweł z Gradzanowa Kościelnego i Łaszewa h. Prawda z urzędem kasztelana sierpeckiego znany jest później, mianowicie wystąpił na dokumencie Siemowita VI z 26 IX 1461 (AGAD, dok. perg., nr 624).

Andrzej z Kanigowa h. Luba urząd kasztelana objął nie w 1472 r., jak podano w Spisach (s. 171), gdyż wystąpił już na sejmie mazowieckim w Zakroczymiu 1 XI 1468 r. z urzędem kasztelana sierpeckiego (AGAD, MK 5, k. 109).

\footnotetext{
25 Jest to wypis z akt grodzkich sochaczewskich, z 1553 r., oblatowanego dokumentu Włodzisława I z 26 XI 1443 r.
} 


\section{Urzędnicy sochaczewscy}

\section{CZEŚNIK}

Można uściślić datę wystąpienia z urzędem cześnika Tomasza z Walewic h. Pierzchała: 2 XI 1471 (AGAD, MK 5, k. 10v).

\section{PODCZASZY}

Mikołaj Plichta ze Skotnik h. Półkozic podczaszym sochaczewskim został przed 2 X 1435 (BCzart., dok. perg., nr 408); wystąpił również na dokumencie Siemowita V z 2 XI 1436 (AGAD, MK 36, s. 908), a nie jak podano w Spisach z 29 X 1436.

\section{PODŁOWCZY}

Stanisław Jeż z Markowa h. Drzewica podłowczy sochaczewski. Można uściślić podaną w Spisach datę roczną jego wystąpienia (1444). Z urzędem podłowczego wystąpił 14 VII 1440 (AGAD, MK 341, k. C 15). Znany jest również później: 1 V 1452 (tamże, MK 337, k. 62); 28 VI 1453 (J. Tęgowski, Matżeństwo Piastówny mazowieckiej, Dodatki źródłowe I, s. 309); 19 VII 1454 (AGAD, MK 335, k. 121v).

\section{SEDZIA}

Wacław z Giżyc h. Gozdawa urząd sędziego sochaczewskiego objął przed 29 III 1418 (AGAD, Błońskie ziemskie I, nr 4 k. 694v).

Grzymisław (Grzymek) z Mikołajewa nominacje na urząd sędziego otrzymał wcześniej niż podano w Spisach. Znany jest: 2 XI 1436 (AGAD, MK 36, s. 908); 18 IV 1438 (BCzart., dok. perg., nr 426); 27 III 1440 (J. Grabowski, Dynastia Piastów, Aneks I, nr 15).

Florian z Bramek h. Dowała z urzędem sędziego wystąpił już 17 VIII 1454 (AGAD, MK 335, k. 131v); znany do 26 IX 1457 (tamże, 335, k. 146v).

\section{STAROSTA}

Jan z Żelaznej h. Rawa starostą sochaczewskim był jeszcze 2 X 1435 (BCzart., dok. perg., nr 408).

Jan Jeż z Markowa h. Drzewica wystąpił jako starosta sochaczewski dopiero 2 XI 1436 (AGAD, MK 36, s. 908), gdyż podana data 29 X 1436 (tamże, MK 36, k. 903-906) jest pomyłką. Dokument Siemowita V ma datację w brzmieniu: Datum et actum in Miedniewicze feria sexta post festum sanctorum Simonis et Jude apostolorum, anno incarnacionis Domini millesimo quadringentesimo tricesimo sexto [2 XI 1436] i znajduje się w MK 36 na stronach 905-908.

Wojciech zw. Chyliński z Chylina z urzędem starosty wystąpił już 1 I 1443 (AGAD, MK 340, k. 145v), następnie 17 X 1443 (tamże, MK 335, k. 156). Jako starosta sochaczewski znany także później: 13 VII 1453 (tamże, MK 337, k. 89); 28 VII 1453 (tamże, MK 5, k. 56v); 28 VI 1455 (tamże, MK 78, k. 170v, jako starosta rawski i sochaczewski).

\section{WOJSKI}

Marcin z Szeromina h. Brody występuje z urzędem wojskiego do 14 VI 1437 (AGAD, MK 336, k. $63 \mathrm{v})$.

Stanisław (nie uwzględniony w Spisach) znany jako wojski sochaczewski 14 IV 1456 (AGAD, MK 337, k. 66).

\section{Urzędnicy wiscy}

\section{KANCLERZ}

Henryk, kanclerz. Przestał pełnić urząd kanclerza ziemi wiskiej na początku grudnia 1382 r. po zastawie ziemi wiskiej Krzyżakom. W zamian otrzymał nominację na urząd kanclerza nadwornego 
Siemowita IV i dzięki poparciu władzy książęcej objął prepozyturę w kolegiacie św. Michała i kanonię w kapitule katedralnej w Płocku.

Stanisław z Gołocina h. Bolesta, kanclerz. W Spisach podano, że wystąpił z urzędem kanclerza wiskiego już 28 XII 1434. Wiadomo z przekazów źródłowych, że ziemia wiska została wykupiona przez Włodzisława I dopiero w marcu 1435 (Iura Masoviae terrestria, t. 1, nr 81, 82) i dopiero wtedy książę mianował urzędników wiskich. Wystąpienie Stanisława z Gołocina z tytułem kanclerza wiskiego na dokumencie z 28 XII 1434 wymaga więc objaśnienia. Analizowany dokument Włodzisława I znany z potwierdzenia Janusza II (z daty: 25 II 1490, Płock, AGAD, MK 6, k. 233v-234v) ma datację w brzmieniu Actum et datum in Ploczko feria sexta infra octavas Nativitatis domini nostri Jesu Christi, anno eiusdem millesimo quadringentesimo tricesimo quarto. Data odnosi się do akcji prawnej (Actum), świadkowie zaś do spisania dokumentu (datum), co nastąpiło najwcześniej w drugiej połowie marca 1435. Jak świadczy formuła scriptum per manus Stanislai cancellarii nostri Visnensis Stanisław z Gołocina spisał oryginał już po nominacji na urząd kanclerza wiskiego. Potwierdza to wpis do Metryki płockiej Włodzisława I z 28 XII 1434 (tamże, MK 335, k. 11-11v), w którym na liście świadków wystąpił Stanisław z Gołocina, jeszcze jako kanonik kolegiaty św. Michała w Płocku i kanclerz dworu książęcego, w brzmieniu Stanislao canonico ecclesie collegiate sancti Michaelis in Ploczko curie nostre cancellario. Także w zapisce z Metryki z 31 XII 1434 (tamże, k. 11v) występuje tylko jako kanonik kolegiaty św. Michała w Płocku i kanclerz nadworny. Stanisław z Gołocina był doświadczonym kancelistą, posiadającym uprawnienia notariusza publicznego. Pracował wcześniej w kancelarii wspólnej Siemowitowiców i z ich nominacji został w 1433 r. kanclerzem ziemskim sochaczewskim. Po podziale Mazowsza (31 VIII 1434) to on zorganizował kancelarię Włodzisława I. Zrezygnował wówczas z kanclerstwa ziemskiego sochaczewskiego i otrzymał awans na kanclerza nadwornego, natomiast po wykupieniu ziemi wiskiej (1435) został kanclerzem tej ziemi. Ustąpił wówczas z kanonii w kolegiacie św. Michała w Płocku i założył rodzinę. Stanisław z Gołocina łączył urząd kanclerza nadwornego z kanclerstwem ziemskim wiskim. Jednak najczęściej z tym ostatnim urzędem występował na dokumentach i w Metryce. Zmarł na przełomie marca i kwietnia 1449.

\section{PODŁOWCZY}

Stanisław Jeż z Markowa h. Drzewica podłowczym wiskim został przed 21 IX 1436 (AGAD, MK 335, k. 79v). Stanisław wystąpił też 21 XI 1435 w Płocku (AGAD, MK 335 k. 105), jako „Stanisław zw. Jerzyk, łowczy wiski”.

\section{PODSĘDEK}

Jan (Jasiek) Roman z Glinek h. Bujno urząd podsędka wiskiego objął znacznie wcześniej niż podano w Spisach. Jako podsędek wiski występuje: 21 II 1439 (AGAD, MK 335, k. 96v); 23 III 1439 (tamże, MK 340, k. 166; tamże, MK 203, k. 46v); 1441 (tamże, MK 336, k. 34). Był on wcześniej zasłużonym geometrą (miernikiem) księcia Janusza I. Po wykupieniu przez Włodzisława I z zastawu ziemi wiskiej (1435) utracił swoje dobra, ale wkrótce otrzymał nowe nadania od księcia i został podsędkiem wiskim. Zob. ostatnio na jego temat: S. Szybkowski, Kredytywa szlachty tomżyńskiej i wiskiej z 31 I 1462 roku dla podsędka wiskiego Jana Romana z Glinek i Stanistawa z Penzy. Z badań nad funkcjonowaniem mazowieckich wspólnot terytorialnych $w$ drugiej połowie XV wieku, „Studia z Dziejów Średniowiecza", 18, 2014, s. 341-343.

Piotr zwany Szorc z Olszyn h. Mora nominację na urząd podsędka wiskiego otrzymał przed 21 IX 1435 r. (MK 335, k. 88-88v). Według Spisów z urzędem podsędka wystąpił po raz pierwszy $10 \mathrm{~V}$ 1435. Autorka powołując się na Zbiory Glogera (t. I) nie zwróciła uwagi, że dokument Włodzisława I z 1435 r. na którym wystąpił Piotr Szorc jako podsędek wiski ma w analizowanej kopii (AP Kraków, Zb. Glogera 66, k. 131-134) błędnie podaną datę dzienną feria 2 in vigilia sancti Stanislai pontificis et martiris glioriosi, do czego doszło w wyniku opuszczenia wyrazu translacionis. Czesław Brodzicki (Początki osadnictwa Wizny i ziemi wiskiej na tle wydarzeń historycznych w tym regionie do 1529 r., 
Warszawa 1994, s. 99), a za nim autorka Spisów, podają datę 10 V 1435, nie jest to jednak możliwe. 10 maja nie przypada w poniedziałek w wigilię św. Stanisława, ale we wtorek po tej uroczystości. Sprzeczność ta znika, jeżeli datację odniesiemy do uroczystości przeniesienia relikwii św. Stanisława. W 1435 uroczystość ta przypada w poniedziałek 26 września. Także tego dnia Włodzisław I przebywał w Wiźnie co potwierdza w pis w Metryce płockiej: in Wyszna feria 2 in vigilia translacionis sancti Stanislai pontificis glioriosi, anno domini etc. XXXV (AGAD, MK 335, k. 32). Wśród świadków dokonanej wówczas czynności prawnej wystąpił m.in. Piotr zwany Szorc, podsędek wiski. Warto przy okazji dodać, że Włodzisław I w dniu św. Stanisława (8 maja) w 1435 przebywał w Bielsku (MK 335, k. 30v), co wyklucza jego obecność w wigilię tej uroczystości (7 maja) w Wiźnie. Odległość między Bielskiem (w ziemi płockiej), a Wizną wynosi ok. $180 \mathrm{~km}$.

Jan Bylica z Jedwabnego h. Trzywdar z urzędem podsędka znany jest później: 31 I 1470 (AGAD, MK 341, k. 11); 15 XI 1472 (MK 5, k. 24); 21 XI 1472 (tamże, k. 25).

\section{SĘDZIA}

Grzymisław (Grzymek) z Mikołajewa nominację na urząd sędziego wiskiego otrzymał przed 21 IX 1435 (AGAD, MK 335, k. 88-88v). Nieprawdą jest (co wyjaśniłem powyżej), że po raz pierwszy jako sędzia wiski wystąpił 10 V 1435, gdyż datę tego dokumentu (AP Kraków, Zb. Glogera 66, k. 131-134) należy rozwiązać na 26 IX 1435. Grzymisław z urzędem sędziego wiskiego występuje także w późniejszych dokumentach: 13 III 1436 (AGAD, Kapicjana 62, s. 121); 20 III 1436 (tamże, MK 80, k. 218); 23 II 1437 (tamże, MK 335, k. 157); 27 II 1437 (tamże, MK 65, k. 86); 6 III 1437 (tamże, Kapicjana 62, s. 163); 10 III 1437 (tamże, 62, s. 344).

Piotr zw. Szorc z Olszyn h. Mora nominację na urząd sędziego otrzymał przed 11 VII 1437 (AP Kraków, Zb. Glogera 60, k. 176). Natomiast po raz ostatni został odnotowany 31 I 1462 i w 1463 r. (Cz. Brodzicki, Poczatki osadnictwa Wizny, s. 114; S. Szybkowski, Kredytywa, s. 335, 349 n.).

Jan (Jasiek) Roman z Glinek h. Bujno. Data końcowa sprawowania urzędu (potwierdzona w źródłach) przypada 5 VII 1468, nie zaś (jak podano w Spisach) w 1471. Zaszła tu pomyłka, gdyż rok 1471 jest datą wpisu (1 VIII 1471, Wąsosz) do Metryki Kazimierza III dokumentu sądu ziemskiego wiskiego wystawionego w Wiźnie 5 VII 1468 r. przez sędziego Jana Romana z Glinek i podsędka Jana Bylica z Jedwabnego (AGAD, MK 6, k. 6-6v).

Mikołaj Słubica ze Słubic, Olszyn h. Prus znany z urzędem sędziego 21 XI 1472 (AGAD, MK 5, k. 25).

\section{STAROSTA}

Grzymisław (Grzymek) z Mikołajewa jako starosta wiski znany jest 3 XII 1435 (tamże, MK 335, k. 106v).

Leonard, rzekomy starosta wiski z lat 1435-1439 (znany autorce z Tek Naruszewicza) nie istniał. Zaszła pomyłka odczytu: Leonardo-Kunrado. Chodzi o Konrada z Niedźwiadnej. Podobna pomyłka występuje w dokumencie Włodzisława I z 30 IX 1437 (AGAD, Kapicjana 62, s. 203).

Konrad z Niedźwiadnej urząd starosty objął przed 14 IX 1436 (AGAD, MK 335, k. 79); znany jest również: 28 IX 1436 (tamże, k. 80); 29 IX 1436 (tamże, Kapicjana 62, s. 96); 13 X 1436 (tamże, MK 340, k. 125); 22 II 1437 (tamże, MK 335, k. 157); 27 II 1437 (tamże, MK 65, k. 86); 6 III 1437 (tamże, Kapicjana, 62, s. 163); 10 III 1437 (tamże, s. 344); 11 VII 1437 (AP Kraków, Zb. Glogera 60, k. 176); 30 IX 1437 (AGAD, Kapicjana 62, s. 203); 18 IX 1443 (tamże, Kapicjana 57, s. 212).

Jan Bylica z urzędem starosty wiskiego wystąpił 11 III 1448 (AP Kraków, Zb. Glogera 60, k. 186). Autorka podała tylko rok (1448), odsyłając do niedokładnej sygnatury (Zbiory Glogera na Wawelu, t. 1 i n.). Jan był później nie tylko podsędkiem, ale również sędzią wiskim.

Jan Siestrzanek z Karnic z urzędem starosta jest znany 13 I 1462 (S. Szybkowski, Kredytywa, s. 349-350) oraz 15 IX 1462 (AGAD, MK 341, k. 9v). 


\section{WOJSKI}

Piotr Żuczek z Kurzeszyna h. Rawa (nie uwzględniony w Spisach) był wojskim wiskim. Z urzędem wojskiego wiskiego wystąpił na dokumencie Włodzisława I z 18 IX 1443 (AGAD, Kapicjana 57, s. 212) oraz we wpisie do Metryki z 15 V 1445 tamże, (MK 337, k. 112v). 4 V 1439 otrzymał nadanie wójtostwa we wsi Kalinowa wraz z 4 włókami (AGAD, Kapicjana 57, s. 460-466).

\section{Urzędnicy wyszogrodzcy}

Dziersław (Dzierżek) z Główczyna h. Awdaniec jako kanclerz wyszogrodzki wystąpił w dokumencie b. d. z 1395 r. (KDMaz., nr 124).

\section{Urzędnicy zawrzeńscy}

\section{PODSĘDEK}

Aleksy z Kocic [Kucic], Głożka [Głużka], Wiśniewa początkowa data to 4 VI 1436 (MK 335, k. 73); podsędkiem był jeszcze co najmniej do 29 IX 1446 (AGAD, MK 335, k. 112).

Andrzej z Kuczborka h. Ogon urząd podsędka objął przed 21 V 1448 (Kraków, Muzeum Narodowe, dok. perg. MNK 533/33).

\section{RZĄDCA (PROKURATOR)}

Mikołaj, rządca zawkrzeński: 7 IX 1440 (AGAD, MK 340, k. 134).

\section{SĘDZIA}

Andrzej Śledź (nie uwzględniony $w$ Spisach) występuje jako sędzia zawkrzeński: 9 VI 1446 (AGAD, MK 336, k. 6v); 29 IX 1446 (tamże, MK 335, k. 112); 9 III 1447 (tamże, k. 114); 31 III 1447 (tamże, MK 336, k. 24v); 21 V 1448 (Kraków, Muzeum Narodowe, dok. perg. MNK 533/33); 19 V 1451 (AGAD, MK 5, k. 19v); 27 III 1452 (tamże, MK 336, k. 127).

Podsumowując nasze powyższe rozważania dotyczące opublikowanego „Spisu urzędników mazowieckich z lat 1341-1462" należy podkreślić, że mimo zgłoszonych uwag i uzupełnień, stanowi on nadal najpełniejszy wykaz średniowiecznych urzędników książęcego Mazowsza. Jeżeli według założeń Autorki spis urzędników miał być uzupełnieniem dwóch części pracy, to brakuje w nim wykazu urzędników dworskich, którzy stanowili najbliższe otoczenie władcy. Potwierdzają to wpisy do Metryki książęcej. Problemem dyskusyjnym jest natomiast brak w wykazie kanclerzy i podkanclerzych nadwornych. Zwróćmy uwagę, jak ważną rolę w procesie przemian ustrojowych odegrała kancelaria książęca. Sądzę, że poszerzenie wykazu o urzędników dworskich i kierowników kancelarii nie sprawiłoby Autorce trudności. Otrzymalibyśmy wówczas wykaz urzędników, podobny do zamieszczonego w dysertacji A. Supruniuk o otoczeniu Siemowita IV. Powyższe uwagi nie umniejszają wartości omawianej pracy, która stanowi wkład w studia poświęcone dziejom Mazowsza w XIV-XV wieku. 


\section{Supplemements and Remarks Regarding „Spis urzędników mazowieckich z lat 1341-1462" (On the Margin of Mazowsze Siemowitów (1341-1442). Dzieje polityczne i struktury wladzy by Anna Supruniuk)}

The dissertation by Anna Supruniuk about the political history of the duchy of Mazovia and its political elite discusses the territory ruled by Siemowit III (1341-1381) and his successors: Siemowit IV (to 1426) and Siemowit V (to 1442). Two parts of this study are supplemented by a list of the land and administration officials from 1341-1462, predominantly from West Mazovia. A. Supruniuk did not take into account the role performed by chancellors (court and land) in ducal Mazovia. A specific feature of this province was the fact that the treasury was the domain of the chancellor and the vice-chancellors; at that time, the competence of the chancellor corresponded to that of the vice-treasurer of the Crown. During the fourteenth and fifteenth century land chancellors too were associated with the ducal chancery. Despite the proposed comments and supplements Spis urzędników z lat 1341-1462 continues to be the most complete list of mediaeval land and administration officials of ducal Mazovia. For this reason, the above remarks do not affect the merit of the work, which makes a considerable contribution to studies on the history of fourteenth-- and fifteenth-century Mazovia.

Kontakt do autora: januszgrabowski@wp.pl 